\title{
PARADIGMS OF READINESS OF NEW VENTURES IN TRANSCENDENCE OF TECHNOLOGICAL PRE-ENTREPRENEURSHIP
}

\author{
Wioletta Czemiel-Grzybowska \\ Faculty of Management, Bialystok University of Technology, ul. Wiejska 45A, 15-351 Bialystok, Poland \\ E-mail:w.grzybowska@pb.edu.pl
}

\begin{abstract}
On the basis of the literature on organizational behavior, strategic changes and technology management this article analyzes readiness of new ventures to function in the framework of technological entrepreneurship. Research findings suggest that objective organizational features are important at the stage of taking decisions, whereas intangible subjective characteristics of a new venture are more important at the stage of taking further decisions. In order to understand the phenomenon of readiness, the research used the data of 112 enterprises applying for establishing their business activity in the project "Academy of Young Businessmen - an opportunity to develop technological entrepreneurship".
\end{abstract}

Keywords: entrepreneurship, readiness, new venture, technological pre-entrepreneurship, development.

JEL Classification: L26; O32; M13.

\section{Introduction}

In today's world, where is competition for customers, the concept of entrepreneurship concerns of each company. For few the centuries, entrepreneurship understood in very different ways. Its importance in the economy depended on the idea and selected the dominant views. From the time of Aristotle to the X-seventeenth century, there had persisted reluctance to traders, merchants and other entrepreneurs. One of the first economic researchers, who used to study the term "entrepreneur" was Cantillon. But Say was the first researcher who defined the term "entrepreneurship". Defining it as a behavior, a consequence of which economic resources are transferred from areas of lower productivity on the area of higher productivity and higher order.

At this moment, entrepreneurship could be described to as a "young" discipline, the modern and open and field based on the boundaries to hinder inquiry. Definition like being "developing", "emerging" and "promising" all lay claim to a state of being where conservative thought has not yet managed to establish themselves, and such notions are key in establishing the identity of a management field.

The main differences between entrepreneurship and technological entrepreneurship are the following that (Venkataraman, Sarasvathy 2001):

- Traditional literature on entrepreneurship focuses on social the role of the entrepreneur in the construction of projects and business processes. While the literature based on technological entrepreneurship also describes also technical factors, eg. technical systems and the institutional environment, including research institutions.

- Technology entrepreneur should, beyond the ability to create new projects, have the ability to anticipate changes in technology and their impact or potential for implementation of development projects.

- Technological entrepreneurship involves entrepreneurship as the dominant of social science with other sciences, including technical (especially achievements in the field of information technology and telecommunications, biotechnology, nanotechnology and renewable energy sources).

The phenomenon of technological entrepreneurship exits when scientific or engineering progress creates a key element of an opportunity which then constitutes the core of a new venture, product or service, an enterprise or even a whole industry. The central role in the phenomenon of technological pre-entrepreneurship is played by an entrepreneurial opportunity whose basis lies in the development of technology. It is a specific case of entrepreneurial behavior of a leader, teams of employees and high technology firms whose creatively constituted product and process innovativeness becomes the main prime mover for building and developing modern enterprises (Baptista et al. 2007; Walicka, Czemiel-Grzybowska 2015).

The article poses the following research question: What factors decide if a new venture is ready for starting business activity making use of new 
techniques and technology (technological preentrepreneurship)?

The answer for this question and the research both focus on the concept of "readiness". The concept of readiness has been already used in the literature on organizational behavior, strategic changes, and in the research on technology management. The literature devoted to organizational behavior examines readiness connected with convictions and attitudes of organization members towards the incoming changes, and takes factors that may accelerate or influence this change into account (Eby et al. 2000; Skowronek-Mielczarek, CzemielGrzybowska 2015). In the literature devoted to the strategic change, the concept of readiness explains the degree to which advantages, processes and activities undertaken by the enterprise indicate if the organization is ready for transformation from the current state to the desired final state (Kaplan, Norton 2004). Technological readiness means readiness of a given individual to use a new technology (Parasuraman 2000; Pearce et al. 2010) or technological readiness for commercialization or technology transfer (Heslop et al. 2001).

An entrepreneur decides if a new venture is ready for being on the make, moving forward despite risk and insecurity of this process. In their research Douglas and Shepherd (2002) elaborated a concept of investment readiness by means of three subareas of readiness: technology, market and management. They concluded that they all can be added to explain the readiness for establishing and developing a new technological venture.

In order to understand the phenomenon of readiness, the research used the data of 112 enterprises applying for establishing their business activity in the project "Academy of Young Businessmen - an opportunity to develop technological entrepreneurship". The analysis concentrated on organizational, strategic, and technological readiness. These three aspects are partly similar to general categories used in the previous research, i.e. features of a start-up team, market and financial features of a new venture, and characteristics of the stage of technological development. The factors are analogous to the categorization by Douglas and Shepherd (2002). The following parts of the article will discuss the concept of readiness, and on this basis a set of hypotheses concerning the influence of readiness on the process of taking decisions to start business activity will be elaborated. Then, the methodology and findings obtained in the statistical analysis will be presented. Finally, research findings will be presented and suggestions concerning future research will be made.

\section{Sustainable definition of technology entrepreneurship}

The most important point for defining the notion of technological entrepreneurship and proposing the operationalization of this term is to present the interpretation of the concept of entrepreneurship. Entrepreneurship is a specific process has involved understanding and reducing major types of risks: market, technology, people and financial. This is accomplished by the dominent combination of vision identyfing strategy and execution.

The frame of external forces impact entrepreneurship and reinforce the need to understand the entrepreneurial process. The most important instance, economic cycles could fluctuate dramatically, fostering periods of optimism those of deep concern and fear. The phenomen ofentrepreneurship can be understood as studying the establishment and development of new enterprises in order to answer for selected questions: Who it assumes? When? Where? Why? As they evolve over time? Studies of entrepreneurship focus on the analysis of creating and exploring new opportunities. At the source analysis of technological entrepreneurship posed similar questions. The most important point is the process of creating and exploring new opportunities.

The concept of technology entrepreneurship has emerged like result of importance's problems with innovation and technology for cinsuption and production. Earlier studies (Beckman et al. 2012; Bailetti 2012; Petti 2012) have shown that technology entrepreneurship can be bridge the gap between entrepreneurship theory and management theory. The phenomenon of entrepreneurship can be analysed simply as a study of the establishment and evolution of new businesses (Nicholas, Armstrong 2003; Walicka, Czemiel-Grzybowska 2015) or as it was stated by Kordel (2015) can be focused on creating and exploring new opportunities. The new of technological entrepreneurship is the process of creating and exploring new opportunities.

The choosen definitions of technology entrepreneurship based on:

1. Opening new ventures.

2. Antecedents of technology entrepreneurship.

3. Special project with technology knowledge.

4. Creative new product and new process innovation.

Term "technological entrepreneurship" is interpreted in few ways and at few levels of analysis, as a system, as a strategy, as a concept connecting 
Table 1. Selected existing definition about technology entrepreneurship (Source: created by the author)

\begin{tabular}{|c|c|}
\hline Years & Definition and authors \\
\hline 1995 & $\begin{array}{l}\text { "Establishment of a new technology venture" } \\
\text { (Jones-Evans 1995). }\end{array}$ \\
\hline 1996 & $\begin{array}{l}\text { "Joint efforts to interpret ambiguous data, } \\
\text { joint understanding to sustain technology } \\
\text { efforts, and persistent, coordinated endeavor } \\
\text { to accomplish technological change" (Jelinek } \\
\text { 1996). }\end{array}$ \\
\hline 2003 & $\begin{array}{l}\text { "Organization, management, and risk bearing } \\
\text { of a technology based business" (Nicholas, } \\
\text { Armstrong 2003). }\end{array}$ \\
\hline 2003 & $\begin{array}{l}\text { "An agency that is distributed across different } \\
\text { kinds of actors, each of which becomes in- } \\
\text { volved with a technology and, in the process, } \\
\text { generates inputs that result in the transfor- } \\
\text { mation of an emerging technological path" } \\
\text { (Garud, Karnøe 2003) }\end{array}$ \\
\hline 2005 & $\begin{array}{l}\text { "Ways in which entrepreneurs draw on re- } \\
\text { sources and structures to exploit emerging } \\
\text { technology opportunities" (Liu et al. 2005) }\end{array}$ \\
\hline 2012 & $\begin{array}{l}\text { "Technology entrepreneurship is an invest- } \\
\text { ment in a project that assembles and deploys } \\
\text { specialized individuals and heterogeneous } \\
\text { assets that are intricately related to advances } \\
\text { in scientific and technological knowledge for } \\
\text { the purpose of creating and capturing value } \\
\text { for a firm" (Bailetti 2012). }\end{array}$ \\
\hline 2015 & $\begin{array}{l}\text { "This is special issue of entrepreneurial lead- } \\
\text { ersip, employee teams as well as high-tech } \\
\text { entreprises, which made a creative product } \\
\text { and process innovation is becoming a major } \\
\text { driving force behind the construction and } \\
\text { development of modern entreprises" } \\
\text { (Stachowicz 2015). }\end{array}$ \\
\hline
\end{tabular}

the ways of technology and marketing innovation, bringing the international technology and business in a profitable trend, but also as an individual approach a process or policy. Another term interpreted as a complex phenomenon multiple disciplines and levels of analysis or it incorporates four main sets of activities relating to: creating new technologies or identify existing technologies (but previously undeveloped); the recognition and matching of opportunities arising from the application of these technologies to emerging market needs, technology development/application, and business creation (Petti, Zhang 2011).

The main themes of world articles on technological entrepreneurship focuses on small technology firms and on external factors that influence the formation of technology firms (Bailetti 2012). The second dominant theme addresses the consequences of technology based business and engineering entrepreneurship (Nicholas, Armstrong 2003). Another, the important theme is the correlation between small-firm initiatives and the external infrastructure that cooperates to science and technology advances. This theme describes the systems that support the foundation and establishment of a new technology venture and different types of technical entrepreneurs (Jones-Evans 1995). Liu et al. (2005) represent ways in which entrepreneurs draw on resources and structures to exploit emerging technology opportunities. The history of technological entrepreneurship is strewn with solutions in search of problems (Venkataraman, Sarasvathy 2001).

The main determinants of development technology entrepreneruship are:

- The openness of the market in product and process innovation and high technology.

- Political and social - economic system of the country.

- Market infrastructure - there are financial institutions as banks, insurance companies, stock exchanges, of course favorable situation is when they operate smoothly.

- The international economic situation, the level of social development and the standard of living of the population and the situation on the labor market and the international financial market.

Technology entrepreneurship is a style of business leadership based on the process of identifying high-potential, technology-intensive business opportunities, gathering resources such as talent and cash, and managing rapid growth using principled, real-time decision-making skills. An attractive business opportunity consists of a great value proposition, technically feasible products, strong intellectual property, a sustainable competitive advantage, a large potential market, and a scaleable business model (Byers et al. 2012).

\section{Theoretical basis of the readiness of new ventures for functioning in the framework of technological pre-entrepreneurship}

Readiness is "the condition of being ready". It is a concept which has been examined numerous times, also in the literature devoted to organizational behavior, strategic management, and technology management. Initial considerations of organizational readiness rooted in the strategic management of human resources define it as access to and an opportunity to acquire skills, resources, and the style of leadership in order to experience leadership and growth (Ratinho et al. 2015; LengnickHall C., Lengnick-Hall M. 1988). A matrix has 
been proposed where the conditions of the organizational strategy and human resources are formulated on the basis of growth and readiness for the change, and comprise skills, styles and experience of organization members. Lately, the concept of readiness has been used to examine convictions and attitudes of organization members towards the incoming change (Fig. 1), taking factors that may accelerate or influence this change into account (Żemigała et al. 2015; Walicka, Czemiel-Grzybowska 2015; Eby et al. 2000).

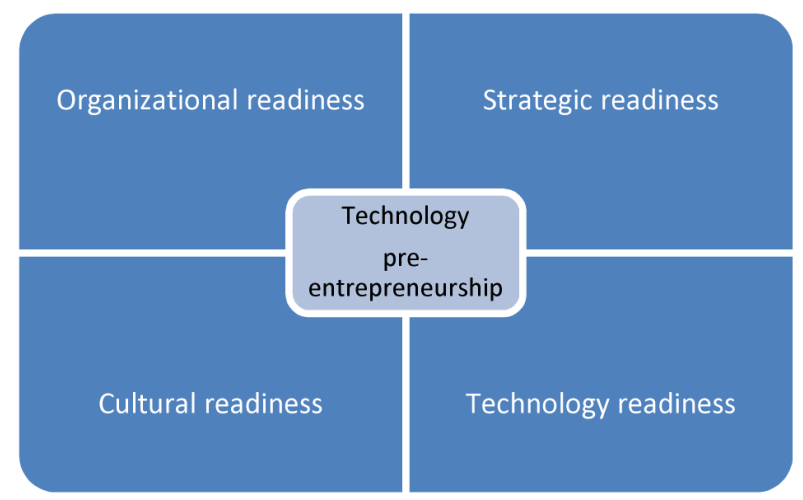

Fig. 1. Readiness with technology pre-entrepreneurship (Source: created by the author)

Ash and Burn (2003) examined the management of ERP (enterprise resource planning) applications in six international organizations. The key conclusion is the statement that cultural readiness, measured by low unwillingness to risk, leadership and open communication, was positively correlated with success.

The key correlate of strategic readiness is diligence in scope of the time needed to implement required strategic changes (Czemiel-Grzybowska 2014; Walicka, Czemiel-Grzybowska 2015). Other studies analyze the level of readiness or the extent to which organization members are engaged in technical innovations and accept them, and the scope of infrastructure the organization has and which is needed to move forward with a new strategy (Jeannett et al. 2005). To conclude, strategic readiness comprises the degree to which the organization's structure and systems are ready for a strategic change, growth and entering new arenas of products and new markets.

Technological readiness differs from organizational and strategic readiness. From the one hand, technological readiness is a system of measures allowing to compare the maturity level of different kinds of technology (Ratinho et al. 2015). Such an attitude indicates the levels of development - from knowledge of basic rules to validation of the product or its components in a laboratory or in the required environment. Researchers of the connected scope of studies analyze technological readiness, commercialization and transfer by means of a constructed model of factors leading to success. The cloverleaf model includes four important factors: the strength of the technology, the market attractiveness, commercialization avenues and management support (Heslop et al. 2001). Other studies focus on the psychological aspects of clustomers' reactions to technologies applied in products or services of a given company (Parasuraman 2000). For the purpose of this research the Technology Readiness Index (TRI) was applied - it measures general readiness for applying a new technology by means of four personality traits: optimism, innovativeness, discomfort, and insecurity. People exhibiting optimism and innovativeness, and little discomfort and insecurity were more prone to apply new technologies (Parasuraman 2000). Other works analyze the role of human capital in the dissemination of the technology in other countries which allows for building skills and capabilities on the individual level essential for technology development (Lengnick-Hall C., Lengnick-Hall M. 1988). To conclude, technological readiness is connected with the evidence of the concept and the acceptance of innovativeness by a given group.

\section{The influence of readiness factors on the process of undertaking technological pre-entrepreneurship}

An analysis of the concept of readiness from the perspective of new ventures may enhance the understanding of the process of starting business activity by technological enterprises.

Hence, it is assumed that all three types of readiness are essential to allow a new business venture to attain the stage of taking decisions on starting highly innovative activity. From the point of view of an analysis of readiness for starting business activity, being focused on an entrepreneur and their team is compatible with longstanding entrepreneurship studies in the literature. Early studies conducted by MacMillan et al. (1987) show that investors in innovative undertakings pay more attention to the entrepreneur and their team when taking their decision than to the market opportunities and potential. Pathak (2013) thinks that the entrepreneur's enthusiasm and sense of trust are the most important criteria when identifying readiness for undertaking highly innovative business activity. In the study concerning investors in innovative 
activities in Poland, Skowronek-Mielczarek and Czemiel-Grzybowska (2015) pointed out that trust and enthusiasm of the managing group were the most important criteria for selecting the most innovative companies.

Similarly, Walicka and Czemiel-Grzybowska (2015) claimed that intangible factors such as the entrepreneur's previous experience may ease insecurity felt by the investor. Furthermore, investors may feel more confident when they invest in entrepreneurs who already have some achievements in scope of establishing and developing a company.

\section{Research methodology}

The data for this research comes from the applications to start a business $(\mathrm{N}=112)$ submitted in the period of two years (2010-2011). The applicants were small new ventures being active for less than five years $($ mean $=3.73)$ and having less than 10 employees $($ mean $=3.86) .57 \%$ of them were active in the sector of technology.

Organizational readiness was described by means of three variables: number of employees employed in the new venture (indicated in the application form), number of employees holding higher managerial positions (counted on the basis of the register of managers in the application form) and experience in a given field obtained by the top managers (on the basis of the category "Management" in the application form; "1" was coded if they have required experience; otherwise " 0 "). Strategic readiness was presented by means of four variables indicated in the application form: a binary variable specifying if the enterprise has customers at the moment, numerical variable concerning the level of development of a new product (a concept for a product was coded as "1", a prototype as "2", a product at the stage of creation "3", a ready product as " 4 ", and revenues generated from sales of a product as "5"), expected revenues in 2015 , pre-money valuation. Finally, technological readiness was depicted by means of a binary variable reflecting if a new venture already possesses its intellectual property in the patent form, or if it has any technology being subject to patent proceedings, if it has a trademark or reserved technology.

Factors connected with the kind of trade and the enterprise have been examined. On the level of the branch, the technological and medical sectors were compared with the sector of consumer goods. On the level of the enterprise, the business model enterprise-customer was examined. Descriptive statistics and correlations are presented in Table.
The next step was calculation of the varianceinflation factor (VIF) for all variables introduced to regressive estimates. It amounted from 1.2 to 1.8 , significantly less that the VIF threshold amounting to 10 , which confirms that multicollinearity was not a problem in the statistical analysis. In order to prevent excessive dispersion, logarithmic transformation of six variables had been used (the number of employees, expected revenues in 2009, premoney valuation, monthly net cash-burn, capital gathered hitherto, and the amount of capital the enterprise is applying for) before they were entered to the seqlogit estimation.

In order to test the factors that influence advancement of new ventures, the procedure of the sequential logit was entered in the Stata software. The model assesses the influence of explanatory variables influencing the probability of passing next stages. A user is able to specify the decision tree as long as the dependent variable may be obtained by only one sequence of transitions.

As every stage (level) of obtained results may be obtained only by one and only one sequence of transitions, seqlogit is a proper statistical technique here. In comparison with an ordinary logistic analysis, sequential logit assumes that a whole chosen set is not simultaneously analyzed. On the other hand, when we know the furthest achieved stage in taking investment decisions, we are able to reconstruct the whole process of the venture's path through difference stages of the investment process. By designating values to dependent variables that refer to progress in going through elimination stages, all cases may be subject to a statistical analysis (Green 2011).

The sequential logit model consists of nested dichotomies and may be estimated by means of indicating the number of logistic models. Similarly to other models, the sequential logit model assumes (1) observation of a dependent variable chosen randomly from a given population; (2) that a dependent variable is an effect of or is associated with independent variables, whereas independent variables are determined by the influence (variables) coming outside of the model; (3) that the relationship between dependent and independent variables is uncertain, which is reflected in the dispersion of observation of the functional relationship. Compared to a regular linear model of regression, maximum likelihood of estimation of the logistic model is solid when it comes to nonnormal errors, non-constant variation of errors, and limitations of the function of reactions stemming from the binary (non-linear) nature of the dependent variable (Green 2011). 
Output statistical data show the estimated influence of explanatory variables on the likelihood of going through individual sequences specified in the tree of decisions. This influence is called the odds ratio (together with corresponding standard errors) or the ratio specifying chances existing in one group compared to another group, or estimation of this ratio on a sample. The odds ratio $=1$ means that a condition or a property may appear in both groups with the same likelihood.

If the value of this ratio is higher than 1 , there is positive influence of the explanatory/control variable, whereas the rate with the value lower than 1 shows a negative relationship.

The results of the sequential logit estimation (Table 2) suggest that at the first stage (deskrejection) one of three measures of organizational readiness (number of top management members) significantly increases the odds ratio for starting highly innovative activity. Two of four measures of strategic readiness (a database of current customers and the stage of product development) are significantly and positively connected with an opportunity to reach the stage of early elimination (deskrejection), whereas the expected revenues in 2015 demonstrates a significantly negative correlation.

Table 2. Sequential logit estimes of the likelihood of the investment process (Source: created by the author)

\begin{tabular}{lll}
\hline \multicolumn{1}{c}{ Variable } & \multicolumn{1}{c}{ OR } & SE \\
\hline Strategic readiness & & \\
Expect revenues in 2015 & $0,65^{*}$ & 0,14 \\
Stage of product development & $1,45^{*}$ & 0,30 \\
Current customers & $2,20^{* *}$ & 0,70 \\
& & \\
Organizational readiness & & \\
Number employees & 0,96 & 0,43 \\
Industry experience & 0,79 & 0,38 \\
Size of top management team & $1,2^{* *}$ & 0,16 \\
& & \\
Technology readiness & & \\
Intellectual property & $1,62^{* *}$ & 0,50 \\
\hline
\end{tabular}

Note: $\mathrm{N}=112 ; *$ significant at $p<0,01 ; * * p<0,05$.

At the second stage (transition sequence) - a presentation for a small group of experts - the number of top management members is significantly and negatively correlated with the likelihood of passing this stage. None of indicators of organizational readiness is correlated with the chance of going through the third stage. When control variables are concerned, localization was an important factor during all transition sequences included in the model.

\section{Conclusions}

Entrepreneurship as a field of management is defined as the exploitation of emerging market opportunities than currently controlled reso-se, that is, to create something. There will provide a new added value. The entrepreneurial management of the company is the permanent search for ways of doing business that will lead to achieving the desired objectives.

The most important factors for development of technology entrepreneurship in building the competitive capacity of the company stems from following their characteristics: their names include the new elements of product, process or sevices; changes are dynamic and creative; everypart of company are associated with other factors that affect the strengthening of the competitive ability, which means the impact on the overall efficiency of the company.

The aim of this article was to indicate factors that influence readiness for starting new ventures. On the basis of the literature on organizational, strategic, and technological readiness, it was examined to what extent new ventures demonstrate some aspects of these kinds of readiness. Organizational readiness for a change is connected with the degree to which organization members have attitudes, experience, imagination, and confidence to follow the change. Strategic readiness comprises the scope to which organization structures and its systems are ready for growth, introduction of a new product or entering a new market; technological readiness comprises a proof of the concept and acceptance of innovation. These three dimensions together constitute general readiness and include three subcategories: market, technological, and management readiness according to Douglas and Shepherd (2002). Research findings show that technological readiness was to the greatest extent different in the process of transition of the venture to further stages of preparing for technological entrepreneurship, whereas organizational and strategic readiness were less important. Technological readiness is measurable more easily from the point of view of the kind of technology and its protection (e.g. prototypes, intellectual property), and from the point of view of customers' acceptance (e.g. sales) (Heslop et al. 2001). Furthermore, strategic and organizational readiness were less important in this analysis and more difficult to measure because of their intangible character (e.g. systems, infrastructure, culture, participants' skills, style and experience) (Skowronek-Mielczarek, CzemielGrzybowska 2015). 
Research findings suggest that despite the fact that entrepreneurs may believe that they are ready for starting technological ventures, in reality they may be governed by the feeling of suddenness than readiness. Readiness may be understood by the entrepreneur in different ways. The research shows that what the entrepreneur may take as the premises of the organization's readiness for starting technological ventures may in fact be a signal of the lack of organizational maturity of the entity. Because of this loophole in perception, there are a few things that the entrepreneur must do to make sure that they are ready to start technological ventures. Due to the importance of objective criteria that a person may take into consideration when taking a decision, entrepreneurs planning to start and develop new technological ventures should at least to a minimal extent make sure that they are technologically, organizationally and strategically prepared. It means that they should possess any kind of intellectual property (pending patent proceedings, patent, trademark), fully formed experienced managing team, a product at the advanced stage of development, and a database of customers (Walicka, Czemiel-Grzybowska 2015). It is an important conclusion that entrepreneurs who were recognized as ready to carry out technological ventures demonstrate, e.g. confidence in carrying out a chosen strategy, passion and capability to convince others to own motivation.

The author is aware of limitations of the research. One of them is still developing theory about technology entrepreneurship, need to creative new definitions and the new frame of research with entrepreneruship technology. New paradigms of technology entrepreneurship will be occured when science and engineering creates a key to chance for new venture, product or service company or branch.

The data is based on subjective information submitted by entrepreneurs. It does not include any information that would be discovered at later stages of the process of taking investment decisions. Despite the above mentioned limitations, the article offers a preliminary analysis of the concept of readiness for technological ventures. The process of taking decisions was divided to well-defined stages allowing for a very detailed analysis. It was proved that all aspects of readiness are important at the first stage of taking decisions; however, measurable personification of readiness is no longer important at the following stages of advancement of technological ventures.

\section{References}

Ash, C. D.; Burn, J. M. 2003. A strategic framework for the management of ERP enabled e-business change, European Journal of Operations Research 146: 374-86. http://dx.doi.org/10.1016/S0377-2217(02)00556-8

Bailetti, T. 2012. Technology entrepreneurship: overview, definition, and distinctive aspects, Technology Innovation Management Review 2(2): 5-12.

Baptista, R.; Karaöz, M.; Mendoça, J. 2007. Entrepreneurial backgrounds, human capital and start-up success, Jena Economic Research Papers 45: 1-39.

Beckman, C. M.; Eisenhardt, K.; Kotha, S.; Meyer, A.; Rajagopalan, N. 2012. Technology entrepreneurship, Strategic Entrepreneurship Journal 6(2): 89-93. http://dx.doi.org/10.1002/sej.1134

Byers, T. H.; Dorf, R. C.; Nelson A. J. 2012. Technology ventures: from idea to enterprise. New York: Mc Grawth-Hill.

Czemiel-Grzybowska, W. 2014. Entrepreneurial orientation in family firms - management and intercultural development, Journal of Intercultural Management 6(4): 181-190. http://dx.doi.org/10.2478/joim-2014-0044

Douglas, E.; Shepherd, D. 2002. Exploring investor readiness: assessments by entrepreneurs and investors in Australia, Venture Capital 4(3): 219-236. http://dx.doi.org/10.1080/13691060213713

Eby, L. T.; Adams, D. M.; Russell, J. E. A.; Gaby, S. 2000. Perceptions of organizational readiness for change: factors related to employees' reactions to the implementation of team based selling, Human Relations 53(3): 419-442. http://dx.doi.org/10.1177/0018726700533006

Garud, R.; Karnøe, P. 2003. Bricolage vs. breakthrough: distributed and embedded agency in technology entrepreneurship, Research Policy 32(2): 277-300. http://dx.doi.org/10.1016/S0048-7333(02)00100-2

Greene, W. H. 2011. Econometric analysis. $7^{\text {th }}$ ed. Upper Saddle River NJ: Prentice Hall.

Heslop, L. A.; McGregor, E.; Griffith, M. 2001. Development of a technology readiness assessment measure: the cloverleaf model of technology transfer, Journal of Technology Transfer 26(4): 369-84. http://dx.doi.org/10.1023/A:1011139021356

Jeannette, P.; Jackson, A.; Ho, K.; Healy, T.; Kazanjian, A.; Woollard, R.; Haydt, S.; Bates J. 2005. The essence of telehealth readiness in rural communities: organizational perspective, Journal of E-Health 11(2): 137-45.

Jelinek, M. 1996. Thinking technology in mature industry firms: understanding technology entrepreneurship, International Journal of Technology Management 11(7-8): 254-269.

Jones-Evans, D. 1995. A typology of technology-based entrepreneurs: a model based on previous occupational background, International Journal of Entre- 
preneurial Behavior \& Research 1(1): 26-47. http://dx.doi.org/10.1108/13552559510079751

Kaplan, R. S.; Norton, D. P. 2004. Measuring the strategic readiness of intangible assets, Harvard Business Review 82(2): 52-63.

Kordel, P. 2015. Przedsiębiorczość technologiczna a trajektorie rozwojowe organizacji, Zeszyty Naukowe Politechniki Ślqskiej 83: 271-282.

Lengnick-Hall, C.; Lengnick-Hall, M. 1988. Strategic human resources management: a review of the literature and a proposed typology, Academy of Management Review 13(3): 454-470. http://dx.doi.org/10.5465/AMR.1988.4306978

Liu, S. S.; Luo, X.; Zhou, L. 2005. Entrepreneurial firms in the context of China's transition economy: an integrative framework and empirical examination, Journal of Business Research 58(3): 277-284. http://dx.doi.org/10.1016/S0148-2963(03)00159-0

MacMillan, I. C.; Zemann, L.; Subba-Narasimha, P. N. 1987. Criteria distinguishing successful from unsuccessful ventures in the venture screening process, Journal of Business Venturing 2: 23-137. http://dx.doi.org/10.1016/0883-9026(87)90003-6

Nicholas, S. P.; Amstrong, N. E. 2003. Enineering entrepreneurship: does entrepreneurship have a role in engineering education?, Antennas and Propagation Magazin IEEE 45(1): 134-138. http://dx.doi.org/10.1109/MAP.2003.1189659

Parasuraman, A. 2000. Technology readiness index (Tri), Journal of Service Research 2(4): 307-320. http://dx.doi.org/10.1177/109467050024001

Pathak, S.; Xavier-Oliveira, E.; Laplume A. O. 2013. Influence of intellectual property, foreign investment, and technological adoption on technology entrepreneurship, Journal of Business Research 66(10): 2090-2101. http://dx.doi:10.1016/j.jbusres.2013.02.035

Pearce, J. A.; Fritz, D. A.; Davis, P. S. 2010. Entrepreneurial orientation and the performance of religious congregations as predicted by rational choice theory, Entrepreneurship: Theory and Practice 34(1): 219-248. http://dx.doi.org/10.1111/j.1540-6520.2009.00315.x

Petti, C; Zhang, S. 2011. Factors influencing technological entrepreneurship capabilities: towards an integrated research framework for Chinese enterprises, Journal of Technology Management in China, Forthcoming 124: 229-235.

http://dx.doi:10.1016/j.sbspro.2014.02.481

Petti, C. 2012. Technological entrepreneurship in China. London: Edward Elgar. http://dx.doi.org/10.4337/9780857938992

Ratinho, T.; Harms, R.; Walsh, S. 2015. Structuring the technology entrepreneurship publication landscape: making sense out of chaos, Technological Forecasting and Social Change 100: 168-175. http://dx.doi.org/10.1016/j.techfore.2015.05.004

Skowronek-Mielczarek, A.; Czemiel-Grzybowska, W. 2015. Entrepreneurship research in the Poland, Technological and Economic Development of Economy 8: 1-16. http://dx.doi.org/10.3846/20294913.2015.1070770

Stachowicz, J. 2015. Przedsiębiorczość technologiczna kluczową siłą rozwoju przedsiębiorstw wysokich technologii, Zeszyty Naukowe Politechniki Ślaskiej 83: 627-639.

Walicka, M.; Czemiel-Grzybowska, W. 2015. Technological entrepreneurship. Managing invention and innovation. Bialystok: RISE.

Venkataraman, S.; Sarasvathy, S. D. 2001. Strategy and entrepreneurship: outlines of an untold story, in M. A. Hitt, R. E. Freeman, J. S. Harrison (Eds.). Handbook of Strategic Management. Oxford, UK: Blackwell. http://dx.doi.org/10.2139/ssrn.275186

Żemigała, M.; Walicka, M.; Czemiel-Grzybowska, W. 2015. Technology entrepreneurship - state of the art and future challenges, Eurasian Journal of Social Sciences 3(40): 10-21. http://dx.doi.org/10.15604/ejss.2015.03.04.002 